\title{
Elements of Ancient European Used in Balinese
}

\author{
I Nengah Martha ${ }^{1 *}$
}

\author{
${ }^{1}$ Universitas Pendidikan Ganesha, Indonesia \\ *Corresponding author. Email: nengah.martha@undiksha.ac.id
}

\begin{abstract}
Lately, many elements of ancient European language are used Balinese youth conversations in meetings. They consist of students, university students, and sekaa truna-truni (groups of youth). They talk about various things, and in their conversation there are elements of the ancient European language. This is very interesting to disclose, especially in relation to: 1) what elements do they use when speaking Balinese? 2) how would the phonemic adaptation form if the elements of ancient European languages were written in Latin script? 3) which sociolinguistic variables influence the use of these ancient European language elements? 4) which elements of ancient European languages are predominantly used? This study uses a qualitative research design, with the object of Balinese adolescent speeches during meetings. So the data is collected in an oral corpus which is then transcribed. Then the data were analyzed descriptively and inductively. This study found the following results. 1) The elements of ancient European languages used by Balinese teenagers when speaking include: a) Anglo-Saxon preffix, Latin preffix, and elements of Greek. b) The form of writing of these elements is adjusted to the Indonesian spelling system which uses Latin script. 3) Sociolinguistic variables that effect the use of elements of ancient European languages are, situation, topic, and receiver-speaker. 4) Elements of ancient European language that are widely used/adopted are Latin elements. Therefore, Balinese teenagers need to deepen their understanding of the elements of these ancient European languages.
\end{abstract}

Keywords: Elements, Ancient European, Balinese

\section{INTRODUCTION}

Can regional languages, which in fact are a form of ascriptive tradition cultural follow the global trend that is full of evolution and technology? [1]. This question sounds like doubting the ability and existence of regional languages as a means of communication between regional residents in an increasingly globalized life. Indeed, many argue that, in order to exist, regional languages must be able to follow the flow of modernization in the global era. Globalization is presumed to have an effect on social changes triggered by information technology and telecommunications are thought to have also influenced the increasing number of foreign language elements entering regional languages. Even the most extreme influence is that regional languages are increasingly being abandoned by speakers, especially by speakers in urban areas. This kind of condition can even have an impact on the loos of regional languages [1].

The premise used for this opinion is that the current of modernization will bring new (coded) concepts, ways of thinking, and behaviour which will be difficult to find word equivalents in the regional language itself. Becouse that word as code is a tool to express what is on the mind of a language user to talk about something [2].

The question now is do all regional languages have the same fate as UNESCO reports? In the context of the world, UNESCO reports that every year there are 10 regional languages that are dead. According to Wurianto the loos of regional languages is conditioned by the penetration of both national and foreign languages [1]. In the Indonesian context, apart from other regional languages, there are still 3 regional languages that are used actively and passively, such as: Javanese, Sundanese, and Balinese. For the Balinese language, the tradition of writing with Balinese script is still productive today. In the contemporary context, Balinese is widely used by younger generation, such as: students, college students, truna-truni groups to communicate about various thing in paruman (meetings). In their conversations elements of ancient European languages are found. It is very interesting to disclouse, especially in relation to: 1) what elements do they use when speeking Balinese? 2) how would the phonemic adaptation form if the elements of ancient European languages were written 
in Latin script? 3) which sociolinguistic variables influence the use of these ancient European language elements? 4) which elements of ancient European languages are predominantly used?

\section{METHOD}

This study focuses on the elements of Anglo-Saxon, Latin, and Greek which are found in speech of Balinese adolescents aged around 15 to 30 years. The Data is taken randomly when they do paruman (meeting) in banjar, village hall, school, campus when they do paruman (meeting) using Balinese. The range of places and locations that are different and quite wide is possible because the researcher, when collecting this data, is in charge of: 1) The head of Balinese language education department (2006 - 2014) who often observes the use of Balinese when they are paruman (meeting). 2) PPL supervisor for students majoring in Balinese language education in schools. 3) KKN mentor in villages all over Bali. Thus data collection was carried out over a long period of time (longitudinal) by taking different adolescents (cross-sectional). Then the data is selected and sorted as needed to answer the 4 problems mentioned earlier.

\section{LITERATURE REVIEW}

How can the twists and turns of penetration of elements of ancient European languages that are far away and have never been in direct contact with Balinese can be part of what is used in speaking in Balinese by todays Balinese young generation? This needs to be answered with relevant literature studies. Literature studies that are considered relevant in relation to this problem are language interactions, language roles, morphological structures. These studies are described below.

\subsection{Interaction of English. Dutch with Anglo- Saxon, Latin, and Greek}

Seen from the geneology/typology of language; English, Dutch, Anglo-Saxon, Latin, and Greek are all cognates, namely the Indo-European family. The use of the Anglo-Saxon by the British occurred, because of the invasion of the Anglo-Saxon people into English, which made the English use the Anglo-Saxon language widely for quite a long time. Until now, the language of AngloSaxon is considered the basic or original of English.

The close territorial relationship between England and the Netherlands (only limited by the English Strait) led to interactions between the British and the Dutch which also affected their language interactions. Roger states "in a situation of contact (the relationship between various nations) languages borrow and borrow phonological, lexical, and semantic units" [3]. Related to this lending-borrowing case, [4] provides an example by stating "Yuddish is a wonderful example of how all languages in contact borrow from each other selectively and of how this very selectively is indicative of the primary interests and emphases of the borrowers and the donors alike" [5].

Latin is the language used by the Roman Empire. The influence of Latin on English occurred when England become a Roman colony. The influence of Latin does not only occur in English but its influence is very wide in the northern regions of Rome, such as: Italy, France, Germany, the Netherlands, and Norway.

A series of victories in Rome's war against Carthage, led to Latin being brought to countries in Mediterranean region, such as Cilia, Sardinia, Spain, and North Africa. And the other hand, it caused Latin to make closer contact with Greek. Contacts with Greek were later extended by conquering the Greek land itself and the Balkans [5].

Greek is a language that is highly respected in the European region. This is because Greek was the first among the West Indo-European languages to carry out civilization. Greek is the language of philosophy, the language of science, the language of literature, and rhetoric. Greek language contact with other western Europeans such as English and Dutch occurs when the nations have an intimate relationship with each other in the European cultural environment [5].

\subsection{The Role of English and Dutch in The Spread of Anglo-Saxon, Latin, and Greek}

As mentioned earlier, that English has a close relationship, and is heavily influenced by Anglo-Saxon, Latin, and Greek. Meanwhile, in the following era, the British nation had a very fast development. English has the most speakers in the world, apart from Russian. English is used in the colony, the commonwealth, as well as in the non-colony country. English is studied at the high school and university level.

In other fields, English has become the language of commerce and markets, and the language of instruction or association in many countries in the world. English is spoken by three-quarters of radio transmitters in the world. In all respects as mentioned above, English is like Latin in the 5th century AD. More than that, English shows the ability to absorb and assimilate by taking so many elements (words, phrases, affixes) from many languages, such as Latin, Greek, French - Normandy.

Despite having received so much influence from other languages, in the course of its history, English has shown the ability of "in" with the ability to create, combine, and simplify in such a way that its vocabulary is the richest in the world, and one of the most precise and most expressive.

In later developments, English tended to be analytical in nature, in which a large number of the same concepts 
with short words were loosely bound by their syntactic tools. There are various ways, how a word can be arranged or formed (lexeme formation) in the case of interactions between languages, namely compounding, affixation, morpheme internal change, and suppletion [6].

In the end today, English has become an international language. The role of English is now so big. English is used in all fields of life.

Regarding the role of English in the international world, has been mentioned in the book of Megatrens 2000 .

From the above description, it appears that almost all areas of information life are penetrated by the use of English, be it information about science, engineering, culture, social, health, diplomacy, politics, economics, and others. The information spread throughout the world through English. Of course, English (which has received the influence of Anglo-Saxon, Latin, and Greek) influenced Indonesian after Indonesian was influenced earlier by Dutch, thanks to the Dutch colonialism of the Indonesian people. The influence of English on Indonesia intensely occurred in the early 20th century unfortunately in Politik Bahasa Nasional it is stated that, what we are picking up is the international language (English). In certain cases, words or morphological elements have long been or first entered through Dutch.

Dutch is the language that has influenced Indonesian more than English. The condition of the Dutch language when it began to influence Indonesian was already influenced by Latin and Greek.

As it known that, the Dutch first arrived in Indonesia (in the Banten region) in 1595 under the leader Cornelis de Houtman. The motive for their initial arrival was driven by economics factors and adventure motives. From economic and adventure purposes, because the Dutch did not want to lose the country of Indonesia which was rich in spices, the Dutch began to grip their claws. The Dutch began to use their political and military forces to control Indonesia. This is evident when J. P. Coun become governor general. Thus, Dutch colonialism began in Indonesia which lasted for three and a half centuries (1595 - 1945) [7].

Since the Dutch colonized Indonesia, the Dutch had a positive and negative influence on the development of Indonesian. In relation to vocabulary, Indonesian takes words and elements from Dutch. The words and elements can be Latin or Greek words or elements which have influenced the Dutch language first.

\subsection{The Condition of The Morphological Structure of The Indonesian Language, and Its Relationship with The Influence of Foreign Languages}

The development of Indonesian cannot be separated from the influence of various languages, both regional and foreign languages. Influences that are easily recognized in Indonesian are affix charges, vocabulary, and other vocabulary elements. The inclusion of affixes, vocabulary, and other vocabulary elements into Indonesian is possible for various reasons, including: 1) Indonesian does need these elements to meet its shortcomings. 2) In its association with international languages, Indonesian requires a means of expression to express various concepts that do not exist in Indonesian. 3) Indonesian can easily accept the influence of other languages or foreign languages, because of its "loose" system (agglutination/ incorporation system). This differs from the analytic language system, or the language system of the flexion where the roles of conjugation and declination become a "bulwark" to enter other language elements.

As it has been understood, the languages of the world have different systems. There are isolation systems, flexion systems, analytical systems, and agglutination/ incorporation systems. These four systems distinguish the typology of language morphology. Indonesian, as well as other "nusantara" languages is included in the typology of incorporation. Morphologically, the characteristics of this incorporation typology are:

1. Has free morpheme and bound morpheme. The formation of derivative words by attaching the boun morpheme to the free morpheme, without being determined by time and person (in conjugasi), and place and function (in declination).

2. Phrase formed by attaching one word to another.

3. The function of a word in a sentence is emphasized more by the affix, not by the case morpheme as in the language of flexion.

The characteristic of this morphological system allows Indonesian to absorb the influence of other languages. This has been proven by Indonesian since it was still called Malay. How many influences from regional languages and foreign languages enter into Indonesian, both in the form of bound morphemes, free morphemes, word roots, and word elements. On the contrary, until there are hybribis formation in the current national language. Of course, this was made possible by the "looseness" of Indonesian language system.

Foreign language elements in the form of complete words then enter Indonesian. Then enter the Balinese language, because Balinese people also speak Indonesian. They speak many things in Balinese. Currently, the dominant languages used in Bali are 
Indonesian and Balinese. These two languages are used interchangeably. This condition has attracted many parties to conduct research on this bilingual case. Interference problems, code switching, code mixing have been expressed by many researchers as reported by Martha [8].

\section{FINDING AND DISCUSSION}

\subsection{Finding}

\subsubsection{The Elements Used When Speeking} Balinese

The use of ancient European language elements found in the speeches of Balinese teenagers, among others:

1) Data $A$

Anglo-Saxon Preffixes:

1) mis-: 'bad', 'badly', 'wrong', 'wrongly'

Example: "Menawi wenten mispersepsi niki, napi sane kaaturang oleh semeton kapertama sareng sane ungkuran?"

2) over- : 'too', 'excessively', 'over'

Example: "Sapunapi carane ngatur nanem palawija mangda nenten overproduksi, sane ngeranayang pengargan ipun mudah?"

3) under-: 'beneath', 'lower', 'insufficient (-ly)'

Example: "Kasela sawi sane katandur olih Sekaa Trunatruni punika becik pisan, iraga dadosne underestimit."

4) up-: 'up', 'upward'

Example: "Yening nenten persetujuan sekaa, sampunan updite berita sane durung janten"

\section{2) Data $B$}

Latin Preffixes:

1) ab- , a-: 'off', 'from', 'away'

Example: "Santukan akeh punyan kelapa ring tepi segara kapunggul, awinan mangkin dados abrasi."

2) ad-: 'to', 'toward', 'near'

Example: "Ngiring iraga beradaptasi santukan iraga mangkin magenah ring desa anak len."

3) post-: 'after'

Example: "Bah sajaan gumi postmodern, luh-luhe badinganga nganggo jaket."

4) bi-: 'two'
Example: "Mangkin gampang ngerereh wantuan saking panegara sane wenten paiketan bilateral."

5) semi-: 'half', 'partly'

Example: "Ceri-cerike dados nginep di posko KKN sambil mebalih sepak bola semifinal."

6) e-, ex-: 'out'

Example: "Sampunang telah punggula punyan kayune ne di rejenge pang ten erosi."

7) im-: 'into', 'on'

Example: "Niki implikasine yening toyane kabagi dados kalih, subak delod lan subak daja."

8) extra-: 'outside'

Example: "Program ekstrakurikuler wenten masi untuk murid-murid SD, Pak."

9) contra-, contro-: 'against' , 'contrary'

Example: "Ngenahang paon ring kaja kauh, kontradiktif sareng sikut umah Bali".

10) inter-: between'

Example: "Awig-awig niki wantah kesepakatan internal ring desa niki kewanten."

11) il-: 'not', 'un'

Example: "Mungkatang kayu sane nenten makta surat izin tebang, illegal nika.'

12) mal- , male-: 'evil' , 'ill' , 'bad' , 'badly'

Example: "Wargi sane katiben malpraktik dados nyaduang ring rumah sakit irika."

13) de-: 'down', 'down from', 'opposite of'

Example: "Izin ngawi pabrik ring masa desentralisasi mangkin aluhan."

14) dis-: 'opposite of' , 'differently'

Example: "Ring galah mangkin akeh panegara sane mabuat disintegrasi."

15) co- , col- , cor- : 'togather' , 'with'

Example: "Kocap wenten korelasine katambetan nika sareng lacure."

16) pre-: 'before'

Example: "Ring statistik desa wenten anak alit sane embas prematur."

3) Data C

Latin Roots Word:

1) am: 'love', 'liking', 'friendliness' 
Example: "Kantun amatir niki, wawu mlajah keterampilan bengkel motor."

2) fin: 'end', 'limit'

Example: "Statistik desane ba finis to gaenin wae?"

3) fluc: 'fluc', 'flow'

Example: "Ajin tabiane jani sing kena ban ngrambang, fluktuatifne keras!"

4) gen: 'birth' , 'kind' , 'class'

Example: "Ne mangkin kan sampun diakui kesamaan gender punika."

5) lateral : 'side'

Example: "Mankin, kayang ring bidang perdagang sampun wenten perjanjian multilateral."

6) here, hes : 'stick'

Example: "Mun ngae pengumuman to, gae nake kalimatne pang padu, kohesif,"

7) litera: 'letter'

Example: "Kenken carane membina SD ne, pang tingkat literasinya tinggi"

8) man, manu: 'hand'

Example: "Sing ada ngaba kalkulator, kanggoang manual gen."

9) script: 'write'

Example: "Suud $K K N$ ne nyidaang apa sing raga mragatang skripsine."

10) simil, simul: 'similar', 'like', 'same'

Example: "Sekonden edengang, simulasikan malu pang nyak ngenah lung nyanan."

11) sol: 'alone' , 'lonely' , 'single'

Example: "Ten ja paduan suara lakar lombaang di 17 Agustuse, nyanyi solo ne kar lombaang."

12) solu, solut : 'loosen'

Example: "Napi solusi sane jagi kaambil indik kekirangan dana pembangunan pura Puseh nika?"

13) vid, vis : 'see' , 'look' , 'sight'

Example: "Luungan tayangan video anggo latarne."
Example: "Lengkapin anake akte kelahirane jak pengesahan pang lebih autentik."

2) crasy: 'government'

Example: "Zaman demokrasi nyen gen dadi ngomong."

3) dem, demo : 'people:'

Example: "Bedik-bedik jani demontrasi rakyate."

4) pan, panto : 'all' , 'complete'

Example: "Sing ja cara ubad, panasea, bisa nyegerang mekejang penyakit."

5) chron, chrono : 'time'

Example: "Penyakit TBC-ne suba kronis."

6) mania: 'madness', 'insane impulse' , 'craze' Example: "Cenik-cenik mangkin, sami sampun keni bola mania."

7) ped: 'child'

Example: "Yen kuliah ring PGSD, polih mata kuliah pedagogi."

8) gen: 'race' , 'kind' , 'birth'

Example: "Ring kota ten wenten malih masyarakat homogen."

9) meter, metr: 'measure'

Example: "Kasane ane alembar to lipet dadi papat, potong di tengah pang simetris."

10) ant, anti: 'against' , 'opposite'

Example: "Yeh klungah inem yen lengehin oong, mengandung antitoksin."

11) onym: 'name' , 'word'

Example: "Pala nika sinonimne merica."

12) nom, nem: 'management' , 'distribution' ,'low'

Example: "Zaman Orla zaman ekonomi keweh"

13) phan, phen : 'show' , 'appear'

Example: "Murid-muride jani sing demen melajah, to suba fenomena umum."

14) therm, thermo: 'heat'

Example: "Termometer anyar to, mara pesuange ken bu bidan."

15) prot, proto: 'first'

Example: "Ne mara conto, prototip adane."

16) these, thet : 'set', 'place' , 'put'

Example: "Kayang uyah jani sistetisa."

17) astr, astro: 'star' 
Example: "Yen melajain Astronomi, mara ja pedas adi bisa ada gerhana bulan, matahari."

18) gram, graph: 'letter' , 'writing'

Example: "Mahasiswa KKN Unud sane dumun, sampun prasida ngaryanang monografi desa."

\subsubsection{The Form of Fonemic Adaptation When Written in Latin Script}

Balinese language actually has its own script, namely Balinese script. The fonts have been prepered on the computer, so that it is possible to write Balinese using Balinese script. Balinese script installed on this computer is called Bali Simbar. Balinese script has been recognized in the world and is classified in the Unicode Standard Version 5. Balinese script uses the basic of Palawa letters [9]. There are 3 types of Balinese script, namely: Modre Script, Wreastra script, and Swalalita script [10]. These three types of characters are still taught in schools, from elementary school to college. Due to the perfected Indonesian spelling, Balinese writing is done in Latin letters. Its phonemic adaptation uses a refined Indonesian spelling basis. Thus, the writing of foreign languages in Balinese also use the enhanced Indonesian spelling rules [11].

The phonemes collected from foreign languages found in this study were adjusted if they were written in Balinese-Latin script, including.

Table 1. The Letters or Phonemes Adjusment

\begin{tabular}{|c|c|c|}
\hline Letters/Phonemes & on & Becomes \\
\hline$/ \mathrm{x} /$ & ex-, extra- & $/ \mathrm{ks} /$ \\
\hline$/ \mathrm{c} /$ & $\begin{array}{c}\text { contra-, contro- } \\
\text { co- , col-, cor- } \\
\text { fluc } \\
\text { script } \\
\text { cracy }\end{array}$ & \\
\hline$/ \mathrm{ch} /$ & chron, chrono & \\
\hline$/ \mathrm{y} /$ & cracy & $/ \mathrm{k} /$ \\
\hline$/ \mathrm{ph} /$ & onym & $\mathrm{li} /$ \\
\hline$/ \mathrm{th} /$ & ghan, phen $;$ & $/ \mathrm{f} /$ \\
\hline & thermo \\
these, thet & $/ \mathrm{t} /$ \\
\hline
\end{tabular}

Specifically, for the preffix post- it is written as pos-, because the phoneme / $t$ / is not pronounced in Balinese. The preffix mal-/ male- is written as mala- which comes from the Sanskrit language with the same meaning, namely 'bad', 'lacking'. Post-, mal-/male- has the status of an affix, it must be written togather/unity with the word attached to it. Likewise, for affix Anglo-Saxon and Latin affixes.

In its use, we also find hybribis words which are a combination of Balinese, Indonesian and foreign languges, as follows.

Table 2. Hybribis Forms in Bainese Language Speech

Hybribis Forms in Bainese Language Speech

updite
kontradiktif
beradaptasi
implikasine
korelasine
fluktuatif
literasine
skripsine
simulasikan
divideokan
sinonimne
sintetisne

\section{Affixes}

-e (Balinese suffix )

-if/-ive (English suffix)

ber- (Indonesian preffix)

-ne (Balinese suffix)

-ne (Balinese suffix)

-if/-(t)ive (English suffix)

-ne (Balinese suffix)

-ne (Balinese suffix)

-kan (Indonesian suffix)

di- + -kan (Indonesian preffix and suffix))

-ne (Balinese suffix)

-ne (Balinese suffix)

\subsubsection{The Sociolinguistic Variables That Effect the Use of Elements of Ancient European Languages}

The choice of code when communicating can be determined by sociolinguistic variables, such as: 
receiver, situation, topic, channel, tone, speaker, and message form [12].
The code choices found in this study are mostly in the form of scientific terms, as in the examples in table 3 .

Table 3. Selection of Loan codes Found

\begin{tabular}{|c|c|c|c|c|c|}
\hline No. & $\begin{array}{l}\text { Selection of Loan } \\
\text { codes Found in } \\
\text { Bainese Language } \\
\text { Speech }\end{array}$ & Science Terms & No. & $\begin{array}{c}\text { Selection of Loan } \\
\text { codes Found in } \\
\text { Bainese Language } \\
\text { Speech }\end{array}$ & Science Terms \\
\hline 1. & mispersepsi & - (vernacular) & 14. & internal & psycology \\
\hline 2. & overproduksi & economy & 15. & illegal & law \\
\hline 3. & underestimit & politics & 16. & malpraktik & medical \\
\hline 4. & update & management & 17. & desentralisasi & government \\
\hline 5. & abrasi & medical & 18. & disintegrasi & government \\
\hline 6. & beradaptasi & psycology & 19. & korelasi & statistics \\
\hline 7. & posmodern & history & 20. & prematur & medical \\
\hline 8. & bilateral & $\begin{array}{l}\text { international } \\
\text { relations }\end{array}$ & 21. & amatir & sports \\
\hline 9. & semifinal & sports & 22. & finis & sports \\
\hline 10. & erosi & geography & 23. & fluktuatif & economy \\
\hline 11. & implikasi & matematics & 24. & gender & psycology \\
\hline 12. & ekstrakurikular & education & 25. & multilateral & $\begin{array}{c}\text { international } \\
\text { relations }\end{array}$ \\
\hline 13. & kontradiktif & - (vernacular) & 26 & autentik & statistics \\
\hline
\end{tabular}

(Identified from the book [14])

The words in the table 3 are $50 \%$ of the word data found. Of the $50 \%$ it turns out that most of them are in the form of scientific terms. This indicates that the topic variable greatly influences the selection of loan codes/words when Balinese adolescents communicate in Balinese. Apparently this also happened in Europe. Elements of the Indo-European language are largely determined by the topic being discussed [12].

In addition, speaker-listener and situation (formalinformal) also influence the use of code or loan words. This can be seen from the choice of the variety of languages (high or low) used by them.

Sociolinguistic variables, such as channel (spokenwritten), tone (tempo, rhythm), messege form (invitation, command) have no effect on codes or words borrowing.

\subsubsection{The Dominant Elements of Anciet European Languages are Used}

From the data collected, the use of Anglo-Saxon language preffixes is obtained by 4 types, 16 types of Latin preffixes are found, 13 types of Latin root words are found, and 18 types of Greek elements are found. Latin element absorbed 2 types, namely prefix (16) and root words (13 types). Its sum are $29(56,86 \%)$. Meanwhile, 18 elements of the Greek language were collecteted $(35,30 \%)$ and the elements of the AngloSaxon language were collected $4(7,84 \%)$. So, the Latin elements is dominant.

\subsection{Discussion}

The interaction between neighboring nations such as the Greek, Latin, English and others in Europe has led to the borrowing of language elements from one another. [3] says, "in situations of contact (relations between various nations), languages borrow and borrow phonological, lexical, syntactical, and semantic units." In the case of lending and borrowing that is long enough, it may be possible to give rise to a new variant called creole starting with pidginization. Creole is a new language resulting from mixing of languages. Creole has the attributes of an indigenous language with languages mixed with it [3] Balinese language is not creole. Balinese language is the native language.

The use of ancient European language elements by Balinese teenagers is borrowed. This loan is forced, because the element borrowed has no equivalent in Balinese. So what happens is code switching. Code switching is one aspect of language dependence in a multilingual society [13]. In this case, Balinese teenagers cannot avoid using other language elements, because in their own language none of these elements are correct. Besides that, they have been familiar with these foreign elements for a long time. A language can be easily used by other speakers when the language has been understood [4].

In general, the diversion of the use of other codes from the language they use is based on awareness as stated by [4] below "the community may be concerned about seeking for the sake of their language, an ancient form which 'cheriched' in ancient times encourage their efforts to support the language associated with the origin and development of new variations of the language ([4], in [3]). Fishman's statement may not be applicable to this case because Balinese teenage speakers are not based on their concern for the foreign language, but on what they know, namely knowing the meaning of the foreign language code. 
To meet the current needs of communication, Balinese teenagers use the opportunity to form words in combination of Balinese language with foreign language codes. Thus, the words hybribis were created. And then, the mixing of first language system and other languages of the two or more languages, can create a new hybrid system containing elements of that language [3].

What brings Anglo-Saxon, Latin, and Greek to the world is English. English itself is an analytic language, which is the formation of words based on the combination of lexemes and affixes. Balinese language is an agglutinative language. Word formation is also based on the attachment of affixes and capital words. The agglutinative system of Balinese language allows Balinese to absorb elements of other languages, which makes Balinese language be survive too. Different from the Sanskrit language which uses a flexion system will become a "fortress" for other language to enter Sanskrit.

\section{CONCLUSIONS}

1. The elements of ancient European languages used by Balinese teenagers when speeking include: AngloSaxon preffix, Latin preffix, and elements of Greek.

2. The form of writing of these elements is adjusted to the Indonesian spelling system which uses Latin script.

3. Sociolinguistic variables that effect the use of elements of ancient European languages are, situation, topic, and receiver-speaker.

4. Elements of ancient European language that are widely used/adopted are Latin elements.

\section{AUTHORS' CONTRIBUTIONS}

The auther has been able to find elements of ancient European languages etymologically so that its can be used as language learning materials for Balinese young generations. The discovery was not only of its origin, but also of its form, meaning, and use.

\section{ACKNOWLEDGMENTS}

I would like to express my gratitude, especially to: 1) the research subjects as the source of the data, which I took while they were not aware of it, 2) the students that I involved in transcribing the data.

\section{REFERENCES}

[1] A. B. Wurianto, Globalisasi, Teknologi Informasi dan Peran Bahasa Daerah sebagai Pencitraan Budaya Nasional, Kliping, Linguistik Indonesia: Jurnal Indonesia: Jurnal Ilmiah Masyarakat Linguistik Indonesia, Th. 20, No.2, 2002, pp. 232 247.
[2] J. Amir, Representasi Kekuasaan dalam Tuturan Elit Politik Pascareformasi: Pilihan Kata dan Bentuk Gramatikal, Linguistik Indonesia: Jurnal Ilmiah Masyarakat Linguistik Indonesia, Vol. 33, No.1, 2013, pp $43-64$.

[3] B. T. Roger, Sociolinguistics: Goals, Approaches, and Problems, London: BT. Bastsford Ltd, 1976.

[4] J. A. Fishman, Sociolinguistics: A Brief Introduction, Massachusetts: Newbury House Publishers, 1975.

[5] M. Pei, Kisah daripada Bahasa, (Terjemahan Nugroho Notosusanto), Jakarta: Bhratara, 1971.

[6] M. Zaim, Pergeseran Sistem Pembentukan Kata Bahasa Indonesia: Kajian Akronim Blending, Jurnal Masyarakat Linguistik Indonesia, Vol. 33, No. 2, 2015, pp $173-192$.

[7] I. N. Martha, Sejarah Perkembangan Bahasa Indonesia, Singaraja: Undiksha, 2011.

[8] I. N. Martha, Research-research Dosen Universitas Pendidikan Ganesha yang Berbasis Local Indigenous: Analisis Meta, Singaraja: Undiksha, 2013.

[9] K. Lama, Bali Kawi, (Diktat) Singaraja: Fakultas Keguruan dan Ilmu Pendidika, 1976.

[10] N. I. Tinggen, Aksara Bali, Singaraja: Penerbit Mutiara, 1996.

[11] N. Bagus, Penyesuaian Penulisan Ejaan Bahasa Bali dengan Huruf Latin, Singaraja: Balai Bahasa, 1975.

[12] J. B. Pride, And J. Holmes, (Eds.) Sosiolinguistics, Canada: Penguin Education.

[13] S. Sosiolinguistik (Edisi ke-2), Surakarta: Fakultas Sastra Universitas Sebelas Maret, 1983.

[14] D., Daftar Kumulatif Istilah. Jakarta: Pusat Pembinaan dan Pengembangan Bahasa, 1984. 